\title{
Migration to South Africa: A missional reflection of a refugee using Jeremiah 29:4-12 as an interpretive framework
}

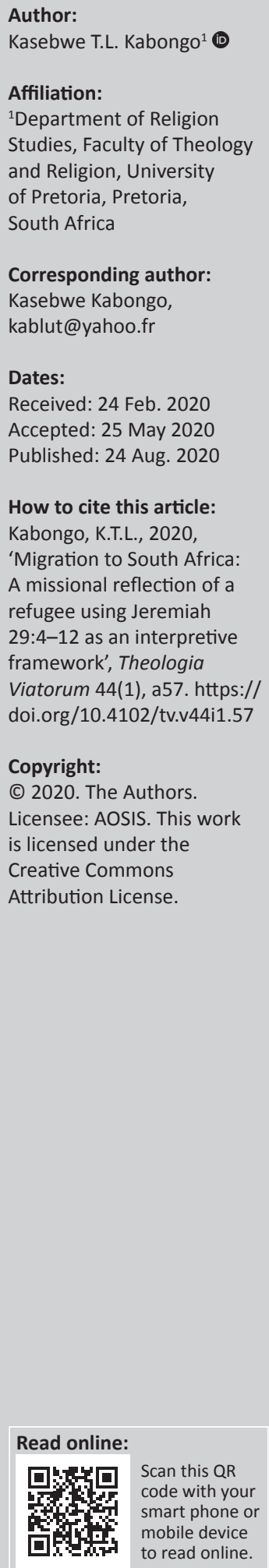

\begin{abstract}
This article is an auto-ethnographic reflection on the phenomenon of migration. The latter is on the increase throughout the world. This article focusses on the context of South Africa where there seems to be a negative perception of refugees in communities of poverty. It uses Jeremiah 29:4-12 as an interpretative framework to, on the one hand, analyse the negative perceptions of refugees and, on the other hand, propose ways refugees could be assets to their host communities. The author is part of a missional team that serves in some South African communities of poverty where refugees have experienced a great deal of discrimination. He reflects on his status as a refugee and a mission worker to point out a constructive role a refugee could play in society as a Christian. He refers to this role as good news agency. The article alludes to practical examples where a constructive role in a community has led refugees to be seen as assets to their communities. It concludes by stressing that the negative perception of refugees in South African communities of poverty may be an implicit collective longing local residents have for good news agents around them regardless of their countries of origin.
\end{abstract}

Keywords: asset; building; good news agents; migration; perception; refugee.

\section{Introduction}

This article is an auto-ethnographic reflection on the phenomenon of migration. It is aware that 'the percentage of people that migrate from one country to another, or from one place to another within the same country, has rapidly increased in the last few years' according to the International Organisation for Migration (2015:1). Such an increase is also real in the context of South Africa. Gordon (2019:270) points out that 'migration is on the rise in South Africa'. Mashau (2019:1) concurs in saying that 'people from different continents have chosen South Africa as their country of residence'.

Migration is not a new phenomenon. Dube (2019:1) points out that it is a recurrent theme throughout the Bible'. In South Africa, it is not new either. Ncube, Bahta and Jordaan (2019:1) say that 'it goes back to close to two centuries, with predominantly people from neighbouring countries'. This old phenomenon has raised new issues and challenges that this research intends to reflect on from an African refugee perspective. An important issue to highlight at this point is that migration is seen as problematic in South African communities of poverty. It has become such a liability that violence between locals and migrants has become a regular occurrence. The author lives in one of the communities of poverty with his family and also serves there as a missionary.

In general, various factors cause migration. Such factors can be the search for better opportunities, 'excessive human capital, unstable politics ... poverty and ... environmental deterioration' (Ncube et al. 2019:2). Migration of Africans to South Africa seems to be caused by both economic and safety concerns. Both these reasons seem to be caused by the push factors and pull factors. Dube (2019:2) explains that in the push factors, migrants 'relocate' to a place they deem safe for them, whereas the pull factors are associated with 'attractive aspects' that motivate migrants to move to a particular location.

The above-mentioned two factors can sometimes be intertwined. So can also be two keywords this research will be alluding to - migrant and refugee. It is important to clarify these terms. All refugees are migrants, but not all migrants are refugees. Chisale (2019:1) says that migrants make the choice to move somewhere, whereas refugees do not make a choice, but are 'forced' to leave their homelands by circumstances that threaten life. The author was also forced to leave his country and now lives in South Africa where he longs to 'embody the humanity of Jesus' and his 
legacy of love in tangible ways in the context of a local community he lives in (De Beer \& De Beer 2018:1). This autoethnographic research aims to reflect on what it means for a refugee to become an asset to his or her host community or country. Auto-ethnography is an approach to research that seeks to describe and systematically analyse personal experience to understand cultural experience (Ellis, Adams \& Bochner 2010:1). The author analyses Jeremiah 29:4-12 with relation to his personal experience as a refugee and an expression of his desire to be an asset to his host country. This biblical passage talks about God's message to a community of refugee alluding to what their attitude and role should be in their host country. This passage has inspired a reflection on the realities of migration being perceived as a liability in South African communities of poverty. It has, at the same time, guided this article to argue a counter-narrative to these negative perceptions. This research is guided by this question: how can a refugee become an asset to his or her host country? The author's journey as a refugee has motivated the asking of such a question.

\section{The refugee}

The author moved to South Africa and became a refugee in 2002 from the Democratic Republic of Congo. Both the push and pull factors influenced his move. A war-torn environment made it difficult for him to thrive in his home country (push factor). A country that was developmentally better than his own, which he could afford to go to, influenced his choice of South Africa as a destination (pull factor). Leaving home meant relinquishing the familiar and venturing to embrace new things such as learning new languages like English, Afrikaans and Sesotho, being a minority, getting immersed into a less communal lifestyle and eating different foods. Pei (2018:208) stresses that as a minority, being misunderstood or marginalised will be familiar realities. You might find yourself inadvertently overlooked or actively silenced. This is a regular experience that has become normal to him.

Being a refugee also meant being a beneficiary of the blessing of his host country. He came with severe health problems which were taken care of, thanks to the good quality of private healthcare in South Africa. He also moved to South Africa as a depressed man who was forced to abandon his dream to become a Roman Catholic priest. He met a missional community, which connected with his sense of calling and led to the ministry he is currently involved with. He also came to South Africa as a single man and married a local person. Together they are blessed with three children. South Africa has also been a fertile infrastructure where he could be a full-time missionary and a post-graduate student. His missionary work has led him to be the continental director of his organisation. Today, he is also a doctoral degree recipient.

In reflecting on his status as a refugee, the author sees his host country as a blessing he would like to reciprocate. He is, however, aware of some of his hosts who dislike refugees like him. According to them, refugees like him are a liability to their well-being. Mashau (2019:1) states that the hosts sometimes tell refugees from Africa 'to go home'. This message is sometimes communicated violently. According to him, the main drive behind this message is 'the reality of job scarcity that many people have to compete for in a South African depressed economy' (Mashau 2019:5). This situation is, therefore, the highlight of a perception that refugees are a liability to locals from communities of poverty. Such a liability may be influenced by ethnocentric worldviews.

\section{Ethnocentrism}

Every human being is ethnocentric. Harris (1995:144) defines ethnocentrism as a 'socially acquired life-way or life-style of a group of people'. Unfortunately, most people are taught to believe that 'their culture is superior to every other group' (Zahniser 1997:84). Many refugees move to their host countries with the main purposes of improving their quality of life and that of their families back home. Many of them live near fellow refugees with whom they share their culture and aims in life. The sense of purpose also influences where people choose to migrate to (pull factor). Riddle (2008:30) observes that for many poor nations, 'individuals living in the diaspora earn relatively higher incomes compared to those earned by individuals living in the country of residence', hence the belief that someone in the diaspora lives comfortably in his or her host country and has enough to help relieve the financial burdens of their family of origin. Borjas (1995:5) confirms that poor countries 'benefit from immigration'. Gnimassoun and Anyanwu (2019:3) state that the roles played by the diaspora, although small, 'contribute positively, significantly and robustly to the improvement of real per capita income in Africa'.

This positive contribution of immigration to the countries of origin should not be carried out at the expense of the refugees in host countries. The author reckons that the ideal posture of an immigrant should be to make a positive impact both in the country of origin and in the host country. In South African communities of poverty, there seems to be a perception that refugees are a liability to the good quality of life of local residents. Such perceptions have led to xenophobic violence on many occasions. Matsinhe (2011:1) states that in democratic South Africa, 'the figure of Makwerekwere' (derogatory name for refugees from Africa) has been constructed and deployed. Violent attacks against Makwerekwere are a regular occurrence throughout the country. From a Christian perspective, refugees are equally God's image-bearers as the locals. They are persons embedded in families, communities and the country. They have gifts, talents, skills and the potential to become kingdom-like, like everyone else (Myers 1999:61-62). For Virgilio Elizondo (quoted by Rodriguez 2003:3), the essential biblical message related to the marginalisation of refugees can be described as 'the Galilee principle'. The latter 'manifests in the incarnation, cross, and resurrection of Jesus of Nazareth' (Rodriguez 2003:3). The Galilee principle is defined as, 'to bring divine blessings to all, God chooses what the world rejects' (Rodriguez 2003:3). It is founded in the sacrificial life of Jesus, the native of Galilee. During that time, nothing good was expected to 
come out of Galilee. 'God chose Galilee to be the starting point of God's human presence among us' (Rodriguez 2003:3). In the bible (Rodriguez 2003):

Jesus does not just do things for the poor and the marginalised, but he identified with them most intimately by being born one of them, learning from them, going to their homes, and eating with them. He is one of them, and he appears to feel comfortable in their company. (p. 3)

The Galilee principle implies that a refugee could be an asset for a host country. It also challenges refugees to learn to overcome some of the common challenges they face in their host country such as being labelled, and they should aim to become good news agents to others. Refugees have been labelled with different derogatory words. Ekblad (2015) rightly points out that:

[L]abelling dehumanises people, reducing them to something much easier to incarcerate, medicate, deport, hate or even eradicate. Labels categorise, entrap, curse and brand us in ways that are nearly impossible to shake. (p. 115)

Ethnocentrism may also push local people to entitlement and a blaming game to justify the current socio-economic miseries South Africa is going through. It is important to bear in mind that like all human beings, local people aspire to 'security, prosperity and equity', and they are frustrated that this ideal does not seem to have the prospect of becoming a reality for the majority of South Africans (McLaren 2001:151).

It is because refugees and their host have equal worth as God's creatures that both their rights and responsibilities in a society have to be stressed. Refugees, in particular, need to meaningfully interact with the realities of marginalisation they face and respond in positive ways. An interpretation of Jeremiah 29:4-12 helps to propose a way such a positive response could look like.

\section{An interpretative framework of Jermiah 29:4-12}

This article interprets this passage to draw out lessons that can equip a refugee to be an asset to his or her host country. In my engagement with this passage, my 'main question is what does the text has to offer and not what is the historical, social and literacy dimension of the text' (Adamo 2018:3). This is, therefore, not an exegesis of the passage but an interpretative framework that is inspired by a particular socio-historical context to analyse a current context.

Jeremiah 29 narrates a story from a context that has plenty of similarities with the current situation of refugees in South Africa. In that context, the Israelites were in exile as a punishment from God because of disobedience. Then came the prophet Hananiah who told the exiled population that God was going to free them and help them return to their homeland after 2 years, which was a lie. Jeremiah revokes this false promise and gives them a message from God. This message challenges the Israelites to settle in, go native and start participating in seeking the peace and prosperity of the context they lived in because they were going to be living in that place for 70 years (Ofo'ia 2017). White (2015) stresses that:

Jeremiah 29:4-7 gives us an idea of how God is concerned about national development and the role believers should play in getting this job done no matter how limited we are. (p. 1)

Brueggemann (2001:18) identifies Jeremiah 29 as 'the clearest model for prophetic imagination and ministry' of participation in community building. Suderman (2014:54) says that it states 'God's commitment to restoration and peace through his children'.

This passage of Jeremiah has been instrumental in helping the author reflect on his role as a refugee in the host society. God's instructions to the exiled Israelites seem to be connected to a contextual message God may be giving to refugees living in South Africa today. This message is consistent with the author's understanding of what it means to be kingdom-like as a Christian.

\section{Jeremiah 29:4-6}

Here God encourages refugees to settle and build houses in their host country, to marry natives and encourage children to do the same so that a multi-cultural nation can start and grow.

In 2008, our family moved to a South African community of poverty to start a missional team whose focus was discipleship and developing community builders from the inside out. We bought a family house because my wife and I were intending to incarnate in this new context of life and ministry. We moved from an upper-middle-class suburb of Pretoria North where I had lived for 5 years. Two years before our move to Soshanguve, we were married. My wife is a native South African. Getting married and moving to live in a township confronted me with the liabilities of both my culture of origin and my host culture.

Getting married to a native was both abnormal and unwise for many close friends from the refugee community and families and friends from my country of origin because we were all raised believing that a functional marriage can only be monocultural. Many immigrant friends who, like me, moved to South Africa as bachelors had their families arrange the marriage of their partners back in their countries of origin and made arrangements for their partners to come and join them in South Africa. Applbaum (1995) states that:

$[A]$ rranged marriages are premised upon the similarity of the social standing of the families of the prospective couple, and the families are very much involved in the process of selecting a marriage partner. (p. 37)

On the other end, my wife made many people close to her uncomfortable by marrying a refugee because refugees have the reputation of marrying natives primarily for selfish reasons. A report published by City Press (2018) states that there is a general: 
$[N]$ egative sentiment towards refugees because most of them get married to locals in order to get citizenship..., many of them are involved in unfair business practices and they use up resources such as housing and the already overburdened public health care. (pp. 1-2)

They are facts pointing out to some refugee involvement in the above-mentioned negative things. Such involvement has tarnished the reputation of the general refugee population of South Africa. It is, however, always unfair to generalise. There is some non-factual sentiment that also drives the negative perception of refugees in some quarters. Hickel (2014:1) states that some perceptions of migrants are influenced by existing beliefs in 'witchcraft', which entertain feelings of anxiety over the socio-economic challenges faced by South Africa. Hickel (2014) shares a story of the sentiment of a middle-aged woman:

When the Makwerekwere come here we no longer develop, and our children no longer progress. If we have reached $80 \%$ then we fall back to 10 or $0 \%$. For example, if I have a shop and a foreigner comes here and sets up a shop nearby, then his shop will succeed and my shop will fail. They will go up and we will go down. The only way to explain this is that they are using something ... that they are using ubuthakathi (witchcraft). You see how they come here, they are poor, they come from a poor country and they come across the border with nothing but a passport. There's no way that they can become rich after only three years or so here! There must be something behind it ... they are using ubuthakathi. There's no other way to explain it. (p. 1)

Hickel's intention is not to demonise locals, but points out that for some of them, refugees and 'witches as morally analogous types of persons - mysterious, antisocial agents that disable productive and reproductive processes'. This negative perception of refugees may be connected to a collective hurt and wound from the past that has not healed yet. Mashau (2019:2) stresses that South Africa has a painful history when at some point native South Africans were 'treated as aliens' and relegated to peripherical locations called homelands. De Beer (2016:4) adds that the movements of the natives were so restricted during that era that one could say that they were denied 'citizenship in their own country'. Some natives militantly opposed these restrictions. They were treated as 'aliens' and violently attacked by government forces (Mashau 2019:2). There was retaliation from natives in various ways. The remnants of that era are still present in current South Africa. They are seen in the 'violent culture' we experience (Mashau 2019:2). Resane (2019:2) points out that some communities see refugees, women and queers as the new aliens; hence, they have become the new recipients of 'social exclusion and violence'. Therefore, a refugee buying a house and marrying a native South African were not the welcomed actions by many suspicious minds. Both these actions were seen as an attempt by an alien to incarnate in a place he was not supposed to.

Some of these negative feelings may cause refugees to isolate themselves from natives and function in bubbles of cultural identities. This is a danger that has the potential to amplify stereotyping and prejudice. Exodus 1 highlights such a danger: separation. In the context of Exodus 1, Hamilton (2011:37) points out that Pharaoh separated the refugee Israelites from the locals as 'a wisdom measure' to prevent clashes between the local Egyptians and the refugee community. According to him, 'Egyptians were infamous for their proud sense of racial superiority towards all other people' (Hamilton 2011:39). Therefore, the mixing of locals and refugees had the potential to not be peaceful. This wise separation became problematic a few years later when a Pharaoh who did not know about Joseph and his legacy in Egypt saw Israelites as a national security threat.

From a personal experience, when a group of immigrants live in isolation from locals, it subjects itself to a plenty of misperceptions and prejudice because it is not incarnated in the host culture. This isolation can be a Goshen-like geography described in Exodus 1. It can be emotional, such as the us or them mentality. It can be linguistic, like the author knows many refugees from Francophone Africa who have chosen to only learn English even though they may be living in a neighbourhood that is predominantly Sesotho speaking. It can finally be social, like refugees socialising amongst themselves only. Isolation can keep local residents strangers to refugees. It is common to hear refugees stereotyping the local residents. It is important to stress, however, that the refugees' entry into a new culture may be slow for various reasons. This could be perceived as isolation or resistance to assimilation. There is also the reality of selective assimilation such as the above-mentioned case of refugees from Francophone Africa, which can be problematic. Isolation may cause some groups of refugees to feed themselves with a climate of fear, victim mentality and hatred, which have led to extremism and terrorism in some parts of the world. The author is learning that being a victim can be a resource to become a blessing to other victims. Such is the case of the late South African journalist Xolani Gwala. He was diagnosed with an advanced stage of colon cancer a few weeks after he had run the London marathon. He used his painful journey with cancer to become a cancer awareness activist. He reflected on his blessing and privileges as someone who could afford the private healthcare treatment, which is very costly, to advocate for many cancer patients who rely on an overburdened and dysfunctional public healthcare system (Talk radio 702 2020). The author is learning that a refugee victim of violence or xenophobia can become an agent of peace in visible ways. This is one of the ways he hopes to proactively participate in building the society he lives in through small, and possibly, other-centred actions of love. Mother Teresa (2016:5022) reminds him that 'love is a fruit in season at all times and within reach of every hand'.

\section{Jeremiah 29:7}

Here God challenges refugees to pray and actively seek for peace and prosperity of their host country because if the latter prospers, refugees will also prosper. 
This is a significant challenge for someone like the author who comes from a cultural context that stresses that someone migrates to an economically well off country for his or her benefit and that of his or her family in the country of origin. The author would like to be a conduit of Jesus' servant leadership in his context. He belongs to a missional Christian order called InnerCHANGE. All of them have committed to serving amongst people living with poverty in a way that can promote Christian principles and good quality of life. It is in those communities of poverty that there has been a great deal of marginalisation against refugees. The founder of InnerCHANGE defines poverty as a lack of love (Hayes 2019:1). He encourages us to be signs of the presence of love in our contexts. He founded InnerCHANGE in 1984 and started being a tangible presence of love to refugees from Cambodia and Latin America whilst living in a poor neighbourhood of Santa Ana in the USA. As he did to these refugees, he encourages a refugee, like the author, to strive to be a tangible sign of love and invite other people around him to be the same. Hence, in InnerCHANGE we value multiplication.

One of the small ways our South Africa team is trying to emulate this legacy of being tangible signs of love has been in starting a reconciliation group between foreign nationals and locals. We have had signs of hope in these interactions as we aim to catalyse community transformation through mutual engagement and cross-fertilisation. We now have locals who are mentored in running a business by foreign nationals. We have also seen foreign nationals come out to testify that as they started being involved in community life and events, their businesses are no longer under threat of being looted. Both locals and foreign nationals are learning to peacefully live together.

Our team has designed a year-long apprenticeship programme in which it recruits emergent local leaders. It trains them to be community builders in being involved in the different projects we have. These local leaders now run our sports ministry (football, basketball, netball and volleyball), tutoring clubs, a drama club, teenager mentoring groups, kids' club and provision of spiritual care for vulnerable children at local children's home. Through these initiatives, we promote community development through mutual solidarity and disciple our neighbours to follow Jesus.

Our team has also been able to connect some of our local leaders to study opportunities through different partner organisations. Education is one of the ways we try to build capacity for our community well-being. Education is a potent asset in helping someone improve his or her understanding of society; it equips people to help in meaningful ways; and it provides opportunities for better jobs that can improve the quality of life of households.

Our team has also been able to facilitate job opportunities of our neighbours by employers from the corporate world. The task of decreasing the current high unemployment rate in South Africa is primarily the responsibility of the government. The author believes that other society stakeholders should also join the government in this task. This is why InnerCHANGE is involved. As a missional team, InnerCHANGE believes that 'employment is a significant engine of community transformation' ( Kabongo 2020:6). Employment empowers people to love and care for other people such as family and neighbours in tangible ways. These efforts are happening in a small community compared with the whole of South Africa. However, as a missional team, InnerCHANGE strives on bringing significant meaning in small ways. Kraybill's (1990:146) encourages us that 'It is easy to do nothing because we fear our small act won't count... However, when several million other people act the same way, the corporate consequences of our behaviour are' felt and seen.

All the above-mentioned things describe how the author interprets being a builder in his host country. The life of Joseph, the son of Jacob, in the bible is inspiring in these efforts. Joseph was also a refugee. Hamilton (2011:23) points that 'although his time in Egypt was largely a prophetic way of God to show and communicate his care for people in desperation', Joseph as a human was a tangible conduit of God's power and wisdom during his life in Egypt. The Israelites lived peacefully in Egypt under the banner of his legacy for many years. Through Joseph, the author has learned the importance of giving his best everywhere he lives.

\section{Jeremiah 29:8-9}

Here God remarks that some refugees are involved in unkingdom-like practices such as fortune-telling. He challenges them to stay away from behaviours that do not honour God and are a bad testimony to his ways.

There is evidence that suggests that some refugees are involved in criminal and illegal activities in South Africa (Hickel 2014:12). A few cases of criminal activities have led to the generalisation of all migrants from Africa, especially those from Nigeria, as bad news to South Africa. Nigerian men are stereotypically described as tall, dark and muscular. The author happens to fit that description. Hence he receives a great deal of unfriendly treatments in places he is not known.

From his experience, he has seen that when someone does well, he or she is seen as an individual. When he or she misbehaves and happens to be a foreigner or from a different ethnic group, people will call him or her by a collective name such as refugees, black people, Zulu and so on. People would jump straight to generalising instead of dealing with individuals. Instead of being a fortune-teller that contributes to the tarnishing of the reputation of refugees in his host context, the author would love to be a catalyst of opportunities that can help build it from the inside out.

\section{Jeremiah 29:10-12}

God encourages a spirit of submission, perseverance and patience to see fruitfulness in life that comes with a future 
filled with hope and success. Despite the negative perceptions of refugees in South Africa, the host communities are very welcoming to people who are an asset to them. This article calls people who are assets and good news agents. The author has started many ministry projects that have always been welcomed by his hosts. Every week, the InnerCHANGE team serves close to 300 children and teenagers. Their parents or guardians are not afraid that their children will be kidnapped when they send them to us. InnerCHANGE runs a substance abuse support group and our community keeps on sending us people to receive help. Submission to God's calling, perseverance in doing biblically inspired actions and patience when faced with negative and suspicious minds have led the author to believe that his host community longs for good news agents regardless of where they originate.

\section{About good news agents}

The author's continued learning of the gospel truth has given him insight into an ideal to pursue in life. He would like to be a good news agent. For him, a good news agent is a follower of Jesus who seeks the peace and prosperity of their context in tangible ways and invites other people to do the same so that quality of life can be improved, lives can flourish and communities can be built from the inside out. Perkins' (1993:44) definition of the gospel inspired this understanding. He defines the gospel as the love of God made visible'. Love agency is meaningful when it is lived out in a specific context and is transferable to other people. If the gospel is defined as good news, then Christians should be good news agents. Good news agency is a praxis deeply rooted in the gospel principles. Hayes (2006:113) stresses that 'the world needs more people to live the good news incarnationally, in a way that can be seen, heard and handled'.

Good news agency also requires prophetic imagination. Brueggemann (2001:3) stresses that the task of prophetic ministry is to nurture, nourish, and evoke a consciousness and perception alternative to the consciousness and perception of the dominant culture around is' to be kingdom-like. Refugees also need to participate in the prophetic imagination of their host country so that they can participate in building it. Instead of thinking that their mission is to only be beneficiaries of the resources of their host, they also need to consider being givers. Their presence is meant to make their host feel blessed, emancipated and empowered. The church could help both the refugees and locals to see each other as 'a reflection of the image of God' whose purpose is to build (Boursier 2017:174). Like Jeremiah 29 shows, God sometimes migrates people, which may be challenging for those who must move. However, the purpose of that migration may be to 'advance his kingdom' in seeking the peace and prosperity of the context someone is moved to (Magezi 2019:11). In those contexts where they have migrated, Africans are also expected to tangibly live out the values of ubuntu of 'love, respect, compassion, care and so on' (Mashau 2019:5).
Dreyer (2015:193) points out a connection 'between theology and ubuntu', where she connects the concept of fellowship to the philosophy of ubuntu. The implementation of the values of ubuntu would challenge refugees to participate with their host 'to the building and transformation of the communities' they live in (De Beer \& De Beer 2018:2). As they immerse into their host communities they will not only discover what they can do to participate in building it, but also their shared brokenness, values and hope for a flourishing future.

\section{Conclusion}

This auto-ethnographic article discussed the missional role of a refugee in South Africa. It used the interpretative framework of Jeremiah 29:4-12 to stress that a refugee is strongly advised to incarnate in his or her host country, to avoid to be involved in illegal or criminal activities and to be an agent of peace and prosperity of that country. It challenged the refugees' mindset as eternal receivers of the hospitality of their host and users of the resources of their host country for their benefit as well as that of their countries of origin. It stressed that refugees are called to be good news agents in their host countries. They should strive to become assets to their host and be active participants in community building. The ubuntu and biblical principles could serve as both a guideline and an inspiration for refugees to be good news agents where they live.

\section{Acknowledgements Competing interests}

The author has declared that no competing interests exist.

\section{Author's contributions}

The author declares that he is the sole author of this research article.

\section{Ethical consideration}

This article followed all ethical standards for carrying out research without direct contact with human or animal subjects.

\section{Funding information}

This research received no specific grant from any funding agency in the public, commercial or not-for-profit sectors.

\section{Data availability statement}

Data sharing is not applicable to this article as no new data were created or analysed in this study.

\section{Disclaimer}

The views and opinions expressed in this article are those of the author and do not necessarily reflect the official policy or position of any affiliated agency of the author. 


\section{References}

Adamo, D.T., 2018, 'Reading Psalm 23 in African context', Verbum et Ecclesia 39(1), a1783. https://doi.org/10.4102/ve.v39i1.1783

Applbaum, K.D., 1995, 'Marriage with the proper stranger: Arranged marriage in metropolitan Japan', Ethnology 34(1), 37-51. https://doi.org/10.2307/3773862

Borjas, G.J., 1995, 'The economic benefits from immigration', Journal of Economic Perspectives 9(2), 3-22. https://doi.org/10.1257/jep.9.2.3

Boursier, H., 2017, 'Faithful doxology: The church's allyship with immigrants seeking asylum', International Bulletin of Mission Research 41(2), 170-177. https://doi. org/10.1177/2396939317693716

Brueggemann, W., 2001, The prophetic imagination, 2nd edn,. Fortress Press, Minneapolis, MN.

Chisale, S.S., 2019, 'An integrated African pastoral care approach to unaccompanied refugee minors based on Verryn's Child interventions', HTS Teologiese Studies/ Theological Studies 75(1), a5478. https://doi.org/10.4102/hts.v75i1.5478

City Press, 2018, viewed 04 August 2019, from https://city-press.news24.com/Voices/ how-fears-about-jobs-drive-anti-migrant-sentiment-in-south-africa-20180814.

De Beer, S.F., 2016, 'Discerning a theological agenda for spatial justice in South Africa: An imperative for sustained reconciliation', HTS Teologiese Studies/Theological Studies 72(1), a3566. https://doi.org/10.4102/hts.v72i1.3566

De Beer, S.F. \& De Beer, W., 2018, 'Change-making in a (post)apartheid city: An autoethnographical essay', HTS Teologiese Studies/ Theological Studies 74(3), a4986. https://doi.org/10.4102/hts.v74i3.4986

Dreyer, J.S., 2015, 'Ubuntu', International Journal of Practical Theology 19(1) 189-209. https://doi.org/10.1515/ijpt-2015-0022

Dube, Z., 2019, 'Jesus - The immigrant Egyptian Jews in Matthew's Sondergut: A migration perspective', HTS Teologiese Studies/Theological Studies 75(4), a5256. https://doi.org/10.4102/hts.v75i4.5256

Ekblad, B., 2015, Erasing labels, viewed 01 June 2018, from http://www.clarionjournal.com/clarion_journal_of_spirit/2015/07/erasing-labels-bob-ekblad.html.

Ellis, C., Adams, T.E. \& Bochner, A.P., 2010, 'Autoethnography: An overview [40 paragraphs]', Forum Qualitative Sozialforschung / Forum: Qualitative Social Research 12(1), Art. 10, viewed 23 July 2019, from http://nbn-resolving.de/ urn:nbn:de:0114-fqs1101108.

Gnimassoun, B. \& Anyanwu, J.C., 2019, The diaspora and economic development in Africa, Working paper series no 308, January 2019, African Development Bank Group, Abidjan.

Gordon, S., 2019, 'A violent minority? A quantitative analysis of those engaged in antiimmigrant violence in South Africa', South African Geographical Journal 101(2) 269-283. https://doi.org/10.1080/03736245.2019.1599413.

Hamilton, V.P., 2011, Exodus: An exegetical commentary, Baker Academic, Ada Township, MI

Harris, B., 1995, Culture, people, nature: An introduction to general anthropology, 2nd edn., Harper International, New York.

Hayes, J.B., 2006, Sub-merge: Living deep in a shallow world: Service, justice and contemplation among the world's poor, Regal, From Gospel Light Ventura, Ventura, CA.

Hayes, J.B., 2019, Speech made at the InnerCHANGE leaders gathering in Cambodia, Novo Foundation, Anaheim, CA.
Hickel, J., 2014, "Xenophobia" in South Africa: Order, chaos, and the moral economy of witchcraft', Cultural Anthropology 29(1), 103-127. https://doi.org/10.14506/ ca29.1.07

International Organisation for Migration, 2015, World migration report 2015, Migrants and cities: New partnerships to manage mobility, viewed 22 Novembe 2017, from https://www.iom.int/world-migration-report-2015.

Kabongo, K.T.L., 2020, 'A partnership for prosperity agency: A case study of InnerCHANGE South Africa', Theologia Viatorum 44(1), a48. https://doi.org/10.4102/ TV.v44i1.48

Kraybill, D.B., 1990, The Upside-Down Kingdom, rev. edn., Herald Press, Scottdale.

Magezi, C., 2019, 'Migration, instrumental to accomplishing God's redemptive purpose to humankind: Perspectives from Ruth and Joshua', In die Skriflig 53(1), a2462. https://doi.org/10.4102/ids.v53i1.2462

Mashau, T.D., 2019, 'Foreigners go home! Re-imagining ubuntology and the agency of faith communities in addressing the migration crisis in the City of Tshwane', HTS Teologiese Studies/Theological Studies 75(4), a5595. https://doi.org/10.4102/hts. v75i4.5595

Matsinhe, D.M., 2011, 'Africa's fear of itself: The ideology of Makwerekwere in South Africa', Third World Quarterly 32(2), 295-313. https://doi.org/10.1080/014 36597.2011.560470

McLaren, B., 2001, The secret message of Jesus: Uncovering the truth that could change everything, W Publishing group, Nashville.

Myers, B.L., 1999, Walking with the poor. Principles and practices of transformational development, Orbis Books, Maryknoll, NY.

Ncube, A., Bahta, Y.T. \& Jordaan, A., 2019, 'Coping and adaptation mechanisms employed by sub-Saharan African migrant women in South Africa', Jàmbá: Journa of Disaster Risk Studies 11(1), a645. https://doi.org/10.4102/jamba.v11i1.645

Ofo'ia, N., 2017, 'Revisiting the Babylonian Exile in Jeremiah 29: 1-14: A Samoan La-tō Reading using an Oceanic Hermeneutic', Doctoral dissertation, University of Otago, Dunedin.

Pei, A., 2018, The minority experience. Navigating emotional and organizational realities, Intervarsity Press Books, Downers Grove, IL.

Perkins, J.M., 1993, Beyond Charity. The call to Christian community development, BakerBooks, Grand Rapids, MI.

Resane, K.T., 2019, 'Demographic change: Ecological and polycentric challenges for white Christianity in urban South Africa', HTS Teologiese Studies/Theological Studies 75(1), a5266. https://doi.org/10.4102/hts.v75i1.5266

Riddle, L., 2008, 'Diasporas: Exploring their development potential', Journal of Microfinance/ESR Review 10(2), 6.

Rodriguez, D.A., 2003, 'No longer foreigners and aliens: Toward a Missiological Christology for Hispanics in the United States', Missiology: An International Review XXXI, viewed 4 January 2017, from http://journals.sagepub.com/doi/ $\mathrm{pdf} / 10.1177 / 009182960303100109$.

Suderman, W.D, 2014, 'Assyria the Ax, God the Lumberjack: Jeremiah 29, the logic of the prophets, and the quest for a non-violent god', Conrad Grebel Review 32(1), 44-66.

Talk Radio 702, 2020, viewed 23 February 2020, from http://www.702.co.za.

Teresa, M., 2016, No greater love, New World Library, Novato, CA.

White, P., 2015, 'Religion, mission and national development: A contextual interpretation of Jeremiah 29:4-7 in the light of the activities of the Basel Mission Society in Ghana (1828-1918) and its missiological implications', Verbum et Ecclesia 36(1), 1-6. https://doi.org/10.4102/ve.v36i1.1419

Zahniser, A.H.M., 1997, Symbol and ceremony. Making disciples across cultures, Innovations in Mission, Marc, Monrovia, CA. 